\section{Mid-American Review of Sociology}

Rooney, J. F. and S. M. Schwartz. 1977. "The Effect of Minimum Drinking Age Laws upon Adolescent Alcohol Use and Problems." Contemporary Drug Problems 6.569-83.

Reis, R. E. and L. A. Davis. 1980. First Interim Analysis of First Offender Treatment Effectiveness: Comprehensive Driving Under the Influence of Alcohol Offender Treatment Demonstration Project. Prepared for the U.S. Highway Safety Administration (Rep. No. DOT-HS-6-01414). Springfield, VA: U.S. National Technical Information Service.

Sykes, G. M., and D. Matza. 1957. "Techniques of Neutralization: A Theory of Delinquency." American Sociological Review 22:664-670.

Williams, A. F., R. F. Rich, P. L. Zador, and L. S. Robertson. 1975 "The Legal Minimum Drinking Age and Fatal Motor Vehicle Crashes." The Journal of Legal Studies 4:219-39.

\section{"IT'S JUST AS EASY TO MARRY A RICH MAN AS A POOR ONE" STUDENTS' ACCOUNTS OF PARENTAL MESSAGES ABOUT \\ MARITAL PARTNERS}

\author{
Jane E. Prather \\ California State University, Northridge
}

Mid-American Review of Sociology, 1990, Vol. XIV, No. 1-2:151-162

Finding appropriate marital partners for their children is a universal concern for parents. In contrast to traditional societies where parents actively seek and select marital partners for their offspring, American society presents the illusion that children have freedom and choice in selecting marital partners. No society, however, really allows people to actually choose their marriage partners on a completely individual basis (Eshleman 1988, p. 254). American parents have not left these important decisions solely to chance. Even though single Americans may assume they are making independent choices, years of socialization lead them to prefer certain categories of persons for marriage and they can only exercise limited freedom of choice (Eshleman 1988 , p. 255). Especially for first and early marriage, couples face considerable social pressure from both parents and peers if they choose to ignore this socialization.

Another American folklore is that couples should only marry if romantically in love (Lee 1982, p. 173). William Goode (1959), however, argues no society allows love to reign without boundaries. Instead, he suggests that societies structure the opportunities and settings where ideal love can occur with higher social classes attempting to exercise more effective control over love than lower classes.

In the United States homogamy in race, religion, occupational class, education, and age range occurs at levels higher than expected by chance (Eshleman 1988; Rockwell 1976; Adams 1979). Even in second marriages where parental influence is usually minimal, homogamy in the above categories is still practiced (Peters 1980).

Over thirty years ago sociologist Marvin Sussman described American parents as threatening, cajoling, wheedling, bribing and in other ways attempting to deter their children from what they considered to be "poor" marriages (1953, p. 80). He noted parents sought to control love by influencing the informal social contacts of their children, through such means as moving into appropriate neighborhoods, sending students to approved schools, and hosting weekend and holiday parties so that children only had opportunities to meet eligible partners.

In Crestwood Heights, a community study of a Canadian suburb, parents asserted that their children's marriages should be based , "...on love, sympathy, compatibility, without regard to race, creed or color or above all--the ugly word!--money." (Seeley, Sim and Loosley 1956, p. 96). Yet, the authors concluded: "the marriages that do occur are not notably different from those 
that might have been arranged in a cast system based upon race, creed, color and money." (p. 97).

What's happening in the 1980s concerning marital choices? Parents of today's college students were themselves seeking marital partners in the 1960s when traditional sexual norms were challenged including "living together" and innovative weddings. How are these parents responding to the dating choices and practices of their children? This paper presents some exploratory research on the mate selection socialization process as recalled by college students.

Students in Sociology of Family classes at a large state university were asked to describe messages that parents, peers, and others gave regarding the appropriate person one should marry. They were asked to respond to openended questions such as: did they received any messages?, what "marital messages" were sent? who sent them?, how were the messages relayed?, and how do the students feel about the messages? One hundred accounts of marital messages were obtained: two-thirds from women, one-third from men representing the typical sex ratio of enrollment for this class. Although the age range was 19-50, the majority of students were in their 20 s with the median age of 22 . Students were predominantly from lower middle to middle class family backgrounds and their religious identification was $38 \%$ Catholic, $28 \%$ Jewish, $23 \%$ Protestant, $8 \%$ no affiliation, and $2 \%$ other (Hindu). Using qualitative data analysis the researchers treated the responses as ethnomethodological accounts in order to gain some understanding of the socialization process by which families transmit their beliefs and values about ideal marital partners.

\section{WHAT MARITAL MESSAGES WERE SENT?}

Most students recalled receiving some messages about ideal marital partners with women obtaining more messages than men. The messages reinforced endogamy in three areas: race, religion, and social class.

1. Race. The most widely practiced endogamy in American society concerns race (Eshleman 1988, p. 278). which in this study was so strongly supported that most parents did not bother to consistently and repetitively send these messages because adherence was assumed. However, when racial messages were sent they contained hostile language:

It would kill me if you married outside race!

If you ever bring home a black girl, I'll break her f-----g legs!

If you ever bring home a black guy, don't expect to have this as your home or me as your father:

Even though racial endogamy was most ardently verbalized about whites dating blacks, some students described prohibitions about interaction with other racial or ethnic categories. For example, an Indian woman revealed that adherence to endogamy for her family included dating only Indian men, which she considered a racial, as well as a cultural category. Similarly, another woman was told to marry an Italian which she de-coded as meaning to marry a Caucasian. Other racial endogamous norms differentiated between marrying vs. dating such as, "It's o.k. to date Orientals, but it's not o.k. to marry them." Being a member of an ethnic group, however, did not necessarily produce mandates to marry within that group:

My mother is half Italian and she always says, 'Why do you go out with Italian guys? Italian men are macho and patriarchal and aren't nice to women.

2. Religion. The most messages that both men and women recalled concerned religion. Not only did families differentiate between Catholic, Jewish or Protestant but they might also specify Protestant denominations or the type of Judaism. Socialization for religious endogamy came from all family members, especially grandparents, beginning as soon as the student was of dating age. The socialization statement could be as direct as, "Make sure she is Christian," or a grandmother's warning: "You'd better marry a nice Jewish boy!" Or transmitted as hints on how to meet the appropriate religious mate such as: "Why don't you go to temple, so you can meet a nice Jewish girl?" Other religious messages centered on why endogamy was important: "Marry someone Catholic so you can have a church wedding" or "...to allow children to be Catholic."

Religious ideals were more strictly enforced when the person was young:

When I was in high school my mother kept telling me to date a nice

Jewish boy, now that I'm in college she just says, "Get married!"

Some messages included a first and second choice: "Marry a Catholic man but if you can't make sure he's Christian." Or "If you're not going to marry within the religion, then at least marry a doctor."

Messages differentiated between dates and potential spouses:

All through my life I can remember my mom pressing the importance of whoever I married to be Catholic. Didn't matter as far as dates or boy friends, just potential husband.

Not surprising, the religious messages were emphasized most among students who defined their family life as religious. The pleas for religious endogamy in contrast to those for racial endogamy did not reflect hostility towards other groups as much as a concern to preserve religious customs and culture. A few students felt their parents wanted them to maintain religious traditions through marriage that had not been emphasized in other ways in the family. Religious endogamy appeared to be even more important for men than women. A female student explained. Her parents believed that regardless 
of her marital partner she would rear any children according to her religion but only if her brother married a woman from the same ethnic background would his children receive the appropriate religious training.

3. Class. Class endogamy was directed most frequently towards women marrying in the same or higher class. These messages often took the form of suggestions rather than mandates and any proposed threats for violating a class rule were more in jest than reality. Though few parents explicitly used the sociological jargon of class or status, they did describe their ideas in terms of family background, occupational potential, and education. Mothers, more than fathers, were likely to send these messages which often consisted of some variation of: "It's as easy to marry a rich man as it is to marry a poor man;" "Marry a middle class man with bucks;" " love is important, but class is more important." Occasionally the questions asked about a date reinforced class endogamy, such as: "What does he do? Does he go to school? Oh, he has his Masters!!!" A few fathers too, reiterated the economic issues but stressed different reasons:

You'd better marry a rich husband, so he can afford to keep you because you're breaking my wallet!

I hope you marry a millionaire! I hope your husband can give you everything you want.

These economic statements could refer to some aspect of a date's job or occupational potential with professions of doctor, lawyer, or dentist being the most popular. In still other cases mothers enthusiastically liked a daughter's date because of his father's occupation: "He's a nice boy---his father owns a store!"

Fathers' comments sometimes focused on the work habits rather than the social class of a potential son-in-law and revealed their own philosophies of life: "Don't marry a quitter," "Find someone who is a good provider, one with a steady job," "Get a real man, college educated, ambitious, goal oriented," "Education is fine, but experience is better."

Mothers' messages could even include advice to not do as she had done:

Make sure he is 'well off' and make sure you have separate accounts.

Don't end up in the same situation I did!!

Class endogamy was linked with other advice for women including a common adage: "Go to college so you can marry a man with education." "Marry someone who has a good job so you won't have to work."

Men, on the other hand, rarely received any explicit messages about the educational, economic, or class status of their dates. In one student's words, "it was assumed that I would marry within the same social class." Only two men could recall receiving messages that could be classified as having any occupational content. One was told to "Marry within the same social class and if she's career-minded, make sure enough time is spent together." Another man obtained a message from his father to marry someone with good economic possibilities such as a nurse. In sharp contrast to the women in the study, only one man was given the message to marry into a wealthy family.

The messages that men did receive from their parents about the possible mates confirmed traditional roles of motherhood or domestic attributes. "Find someone who will want to be close to home and can communicate well with kids." Domestic skills about future daughters-in-law were stated in a variety of subtle ways: "Marry someone who can cook Italian food." Parents were also concerned about their relationship with their potential daughter-in-law, "Make sure she wants to visit us after marriage and be sure she can communicate with us."

Thus, the women, in contrast to men, remembered messages about social class expressed through occupational status and education. Evidently, parents still considered the potential son-in-law to be the primary economic supporter of their daughter. Consequently, a daughter's potential marital partner was extremely important to the parents and they apparently did not miss opportunities to communicate that she should ideally seek a man of higher social status. While men were encouraged to look for an attractive woman with some housewifery skills the women were warned about the importance of finding a mate with outstanding occupational skills or educational accomplishments. Parents apparently emphasized the quality of the relationship to their sons while stressing the economic quantity of marriage to their daughters.

Other messages acquired by students related to age, time of marriage, appearance, substance abuse or divorce. Men obtained different acceptable age references than did women. Parents warned men not to date older women, but some recommended women seek an older partner who they believed "would be more economically stable and more settled in their job." Women also acquired more information than men about the appropriate time in life to marry.

Don't rush to get married. Enjoy yourself because after you marry you can't do what you want. Never marry young.

An opposite concern was also expressed to a woman who is not yet 20. "You have two more years to make the choice, otherwise, you'll be over the hill."

While women learned about age and timing of marriage, men acquired comments about the appearances of their potential mates: "Can't you find a good looking one?" Or "Don't marry anyone fat!" Appearance advice to women emphasized height more than weight: "Find someone who is at least taller than you."

Several female students received warnings about a date's use of alcohol and drugs or cigarettes. Other miscellaneous messages included political affiliations such as find someone with liberal views or even the 
recommendations of the actual political party membership: "Find a Republican, oriented to the good life."

Surprisingly, there were few comments concerning sexual experience or virginity. Only one student reported his family's insistence that he find a virgin. Another man felt his father treated virginity as a joke for whenever a young lady spent the night at his house, his father would say to him, "Well, you can't marry her." Instead of concern about sexual experience, parents made reference to the stigma of divorce:

You don't need a man that's already used (divorced) or someone else's leftovers!

Don't bother with him if he's divorced and has children!

Men, too, were admonished not to marry a divorced woman especially one with children whom they might need to support.

\section{HOW MESSAGES WERE SENT}

The most common time for message-sending was when a student returned from a date or mentioned a date had been made at which time comments would be made:

I don't think she is the right one for you. She has not proven herself trustworthy. She comes from a different kind of family life.

You always look so tired, I think Sally brings you down. She's not good for you.

Some marital advice incorporated humor:

When you meet a guy you think you might marry, picture him bald, naked, sitting on the toilet and reading the Sunday funnies--if you can tolerate that; he's yours!!

Another sending style was to ask rhetorical questions about dates such as "Aren't you too young to be getting so serious?" "Don't you think you should date more than one man?" Still another procedure was to remind the student of the endogamous rules before a potential date was called: "Remember I want you to date only Christians."

One man's father made different comments about a date's appearance depending upon whether she was the appropriate religion. An unapproved date, would be described as "Dave, she's ugly!" while the acceptable one would result in the opposite statement: "Dave, she's really pretty!" Another student noted his parents and his sister would frequently mention dates they liked while ignoring those they disliked:
What ever happened to

? How come you don't bring her around? She's such a nice girl. Why don't you invite her to dinner?

Other methods of showing disapproval included parents' refusing to speak to dates they disliked or adjusting curfew times depending upon their opinion of the date. Similarly, a man reported that his father would only pay for a date when the woman was orthodox Jewish. If the woman was conservative Jewish, the father never volunteered to pay.

Students identified the most powerful way of reinforcing marital messages was to forbid the man or woman from seeing or dating an unacceptable partner. The success of such disapproval probably depended upon the amount of respect that offspring felt they owed their parents. For example, a traditional Hindu Indian woman was never permitted to date any one man except an Indian of the same caste and occupational category. Bribes or gifts were also used to encourage the correct endogamous match. Men reported offers of a house or a large inheritance if they married the right woman: in one case, the appropriate religion; in another, the same ethnic nationality.

In addition to parents, brothers and grandmothers found ways to express their opinions. A brother preferred, "Someone we can play basketball or football or baseball with on Sundays." Grandmothers, too, sent messages, particularly expressing eagerness to see granddaughters married:

Ever since I've been out of high school my grandmother is constantly telling me how I should be married.

Another grandmother, jokingly, kept asking when a wedding would occur because: "Give me time to get a dress for the wedding." A woman who was raised by her grandmother, remembered her being so strict about the kind of men she could date that "It was easier to bring home a stray dog than a boy into my grandmother's house." The grandmother would send a younger sister along to chaperon a date.

Single mothers reported children were very particular about their dates and sons are very protective towards mothers while daughters were less restrictive about their mothers' boyfriends.

My teenage son is worse than my father ever was! No date is ever good enough for me!

Not only family but also other socializing agents made recommendations about marital partners as this woman recalled about the church's role:

We were sent to Catholic schools, elementary, high schools and college and I think this gave us a million messages in and of itself-everything from religious to social and economic to location. 


\section{HOW STUDENTS RESPONDED TO ENDOGAMOUS NORMS}

Most students reacted positively to the messages saying they agree with all of them or would relay same messages to their own children.

I agree with my grandma, I would not marry outside my religion. And I guess I agree with my dad, I would want to marry someone who made more money than my dad because I wanted things he couldn't afford to give me.

My parents want me to find a nice intelligent Jewish girl because they say looks aren't everything; I agree with finding a Jewish girl but I would like a girl with looks as well as intelligence.

Others stated they disagreed but understood their parents. Only a minority of students objected to the messages with most disagreement occurring over religion:

My father directly says that I should marry someone within my own religion (Jewish) but I think they make a bigger problem out of it than I do.

Religion: It's ridiculous. They made a bigger problem of it than me. Race and ethnic group: Parents don't have any right to say what you do.

Another student felt her mother's message to find a future husband who was college educated unrealistic:

My mother wants me to marry someone with lots of money and in the medical occupation. But this is a fallacy because guys with lots of money usually don't marry girls without!

Surprisingly, only a few students thought their parents gave too many messages. Most interpreted the messages as their parents were showing concern for them.

\section{DISCUSSION}

This paper illustrates some of the ways in which American college students perceive they have been socialized to adhere to endogamy in race, religion, and social class. The findings correspond to current literature on mate selection. For example, these students reported that parents were most vehement in their expressions about racial endogamy. The sanctions for not adhering to racial endogamy were delivered as hostile and violent threats. Racial homogamy is the most rigorously enforced mate selection norm in the United States (Eshleman 1988, p. 278) and until 1967 states could legally outlaw racial intermarriage (Wilson, 1984). Although interracial marriages have increased in the United States since the Supreme Court ruling, their occurrence is still infrequent (Eshleman 1988, p. 280).

Both male and female students received frequent messages to select partners of the same religion, especially if students deemed their families as religious. Concerns about marrying within the same religion, unlike those for preserving racial homogamy, did not convey such intense negative feelings about "outsiders." Students perceived the point of these parental feelings about racial endogamy as a need to preserve a family's religious and cultura traditions. Several national studies (Carter and Glick 1976; Glenn 1982) confirm that religious homogamy is strongly adhered among American couples. Almost $90 \%$ of all Protestants, Catholics and Jews have spouses of the same religion (Glenn 1982).

Of special note in this research was the pressure placed upon young women to marry within the same or in a higher economic class. As suggested by the title of the paper, most young women had heard this message even if it were stated in jest. The parental and grandparental recommendations to strive for class hypergamy (females marrying into higher social strata) or to preserve class endogamy, however, were transmitted in a tone subtler than those about race or religion. Historically, class endogamy has been practiced in American marriages. A summary of the research on class endogamous marriages for the past fifty years (Eshleman 1988, pp. 268-69) reveals that men and women marry within their own class with a greater consistency than could be expected by chance. In studying the American upper class, Domhoff $(1983$, p. 34) suggests that the prevailing wisdom among the members of this elite is that children should marry someone of their own social standing. Hence, the upper classes sponsor the debutante season for the purpose of introducing young women of the upper class to eligible marriage partners. "The function of directing romantic love into acceptable channels was taken over by fraternities and sororities, bachelor and spinster clubs, and exclusive summer resorts (p. 34)."

In spite of increasing trends for American married women to be participants in the paid work force (Beeghley 1989, p. 227), most parents, as illustrated in these students' accounts, still view the economic class of their daughter's future husband to be vitally important. Studies on dating attitudes report that women, too, admit they look pragmatically at the man's education and earning capabilities (Huston and Ashmore 1986 in Lips 1988, p. 252) The tradition of the woman planning her economic future by the economic status of her husband suggests that women may tend to be more practical in their mate selection perspectives while men's choices are more romantic (Adams 1979, p. 264; Lips 1988, p. 211). Although the men in this study did not experience parental pressure to select a partner who could improve their economic standing, they did receive such traditional messages as finding an attractive woman, or a woman who could demonstrate homemaking skills and would desire motherhood. Research on college students reveals men place greater significance on physical attractiveness of their dates than do women 
(Deaux and Hanna 1984 in Basow 1986, p. 211) and most male students state a woman who combines family and career is a more desirable marital partner than a traditional homemaker (Hollender and Shafer 1981 in Basow 1986, p. 210).

A variety of people sent the mate selection messages--parents, grandparents, and siblings. Brothers provided more direction and suggestions to their sisters than the reverse. Brothers advocated sisters find someone whom they could relate through activities such as sports. Grandparents were most adamant about maintaining religious endogamy. The active role of brothers in mate selection advice probably relates to traditional patriarchal norms that brothers should protect sisters.

Historically marriage holds a highly valued status in societies. Recent studies of college students indicate that goals of being married and having children are even more popular in the 1980s than in the previous decade (Renzetti and Curran 1989, p. 131; Basow 1986, p. 212). Although some mothers in this study expressed concern that their daughters not marry too young, they were still eager for their daughters to be married rather than single. The female students recalled their mothers gave more proscriptions than fathers while the college men received fewer messages about when and whom to marry. Novelists such as Jane Austen as well as sociologists (cf. Sussman 1953) describe mothers taking an active role in creating the opportunities for their daughters to meet appropriate spouses. One method is planning the elaborate and expensive Debutante balls to announce the arrival of the young, upper class woman into society (Domhoff 1983, p. 32 33). Furthermore, mothers can take credit if the ideal match--hypergamy (marrying into a higher social class) occurs.

Concerns about exogamy (the groups one should marry outside of such as sex or immediate family) were not typically mentioned unless parents perceived some special circumstance to merit discussing such an issue as in the case of one male respondent who was considering a gay life style. Perhaps these findings indicate these cultural norms are so strongly internalized, they do not need to be verbalized. Moreover, as feminist Adrienne Rich implies the societal disdain for homosexual relationships is often exemplified by silence. In her treatise she argues that society perpetuates. an ideology that heterosexuality is compulsory (Rich, 1986).

Although students in this study were cognizant that parents had strong preferences about the social characteristics of potential marital partners, most students did not state their parents' opinions were out of line. Only a minority of students perceived threats for deviation such as the family disowning them. Since most of these students were not married, the impact of the marital messages remains to be seen.

The movement for gender equality does not appear to have led to egalitarian relationships nor altered traditional mate selection norms Although college students profess that equality in dating relationships is the ideal status, most student couples admit their relationships are unequal (Peplau 1984). Women are still being socialized to find partners that are taller, older, more educated and wealthier than they are (Bernard 1972). Men interpret this message to imply they must have more power and money in order to appeal to women (cf. Farrell 1986): Similarly, husbands report being threatened if their wives' employment is greater than theirs in prestige, threatened if their wives employment is greater than theirs in prestity of mate selection has led to a situation labelled as 'the cream of the crop and the bottom of the barrel' (Bernard 1972) or called the mating gradient (Leslie and Korman 1985). According to these perspectives, traditional mate selection socialization results in only a small pool of acceptable potential mates for the highest status women (cream of the crop) and the lowest status men (bottom of the barrel). This pattern is observed in the college scene where presumably the freshman male and the senior female have the smallest choice of potential dating partners while the freshman woman and the senior man have the most possibilities (Eshleman 1988, p. 271). As this paper suggests, some university women are receiving a message to find a partner at least economically women arior to them. Although men in our study did not report being socialized to locate a partner of lesser social status, only a few men were encouraged to find a career-oriented partner. Thus, although the gender revolution has changed occupational opportunities leading to more non-traditional careers for both men and women, at the same time traditional norms of mate selection are still transmitted by parents, grandparents and siblings. Whether these marital messages will necessarily be adhered to, remains to be seen. Yet, if the current trend continues for men and women to marry at a later age (Eshleman 1988, p. 259) and hence undergo longer career preparation, perhaps marital choices will be more autonomous and the messages have less impact. Moreover, if women in the next decade begin to reach economic parity with men, the old adage that it is just as easy to marry a rich man as a poor one may become an historical legend rather than an economic imperative.

\section{REFERENCES}

Adams, B. 1979. "Mate selection in the United States: A Theoretical Summarization." Pp. 259-67 in Contemporary Theories About the Family, edited by W. R. Burr, R. Hill, I. Nye, and L. Reiss. New York: Free Press.

Basow, S.A. 1986. Gender Stereotypes. Belmont, CA: Wadsworth.

Beeghley, L. 1989. Social Stratification. Boston: Allyn \& Bacon.

Bernard, J. 1972. The Future of Marriage. New York: World Press.

Carter, J. and P. C. Glick. 1976. Marriage and Divorce: A Social and Economic Study Cambridge: Harvard University Press.

Dimon and Schuster.

Eshleman, J. R. 1988. The Family. Newton, MA: Allyn \& Bacon.

Farrell, W. 1986. Why Men are the Way They are. New York: McGrawHill. 


\section{BOOK REVIEWS}

Farber, B. 1964. Family Organization and Interaction. San Francisco: Chandler. Glenn, N. D. 1982. "Interreligious Marriage in the United States: Patterns and Recent Trends." Joumal of Marriage and the Family 44:555-66.

Goode, W. 1959. "The Theoretical Importance of Love." American Sociological Review 24:38-47.

Jedlick, D. 1984. "Indirect Parental Influence on Mate Choice: A Test of the Psychoanalytic Theory." Journal of Marriage and the Family 46:65-70.

Lee, G. R. 1982. Family Structure and Interaction: A Comparative Analysis. 2nd ed. Minneapolis: University of Minnesota.

Leslie, E. R. and S. K. Korman 1985. The Family in Social Context. New York: Oxford University Press.

Lips, H. M. 1988. Sex and Gender. Mountain View, CA: Mayfield Press.

Peplau, L. A., 1984. "Power in Dating Relationships." Pp. 100-12 in Women, edited by J. Freeman. Palo Alto, CA: Mayfield Press.

Peters, J. F. 1980. "A Comparison of Mate Selection and Marriage in the First and Second Marriages in a Select Sample of the Remarried Divorced." Pp. 419-26 in Cross-Cultural Perspective of Mate Selection and Marriage, edited by G. Kurian. Westport, CT: Greenwood Press.

Pleck, J. 1978. The Work Family Role System." Social Problems 24:417-427.

Renzetti, C. M. and D. J. Curran. 1989. Women, Men and Society. Boston: Allyn and Bacon.

Rich, A. 1986. "Compulsory Heterosexuality and Lesbian Existence." Pp. $23-$ 75 in Blood, Bread, and Poetry, selected prose by A. Rich. New York: Norton Co.

Rockwell, R. C. 1976. "Historical Trends and Variations in Educational Homogamy." Journal of Marriage and the Family 38:83-95.

Seeley, J. R., R. A. Sim, and E. W. Loosley. 1956. Crestwood Heights. New York: Basic Books.

Sussman, M. 1953. "Parental Participation in Mate Selection and Its Effect Upon Family Continuity." Social Forces 32:76-81 Wilson, B. F. 1984. "Marriage's Melting Pot." American Demographics 6:34-
37.
Robert J. Antonio and Ronald M. Glassman (eds.), $A$ Weber-Marx Dialogue. Lawrence, Kansas: University of Kansas Press, 1985. xxi + 334 pp.

In the English-speaking world it is only in recent years that Marxists and Weberians have begun speaking to each other. Undoubtedly this dialogue has been spurred by substantive analyses in critical theory that have gone beneath the surface Marxism of the Frankfurt School and into the Nietzschean sources that also inform this European trend. To complete the frame out of which this new interaction has emerged, we also find at either "end" of critical theory, that is, in Lukacs and Habermas, there is an important engagement with Weber.

The presence of Nietzsche in this configuration is highly significant: this presence is perhaps the most important factor in explaining the long forestalling of an explicit, open, and not purely antagonistic Marx-Weber dialogue. Marx is discussed in many departments of the contemporary university. In the United States, however, Weber remains confined mostly to the sociology department, while Nietzsche is found (hopefully) in philosophy and sometimes in German language and literature departments. My point is that a Marx-Weber dialogue is, and needs to be recognized as, a MarxNietzsche encounter; and necessarily so, for Weber was much influenced and informed by Nietzsche. The absence of a real encounter between Marx and Nietzsche (which is obviously correlated with the disciplinary separation between philosophy and sociology--a separation that critical theory seeks to overcome) has therefore been a detriment to the emergence of a substantive Weber-Marx dialogue. (Incidentally, and by the same token, the interest in Foucault in literary circles could certainly be well-served by a reading of Weber, as some respects of Foucault's work can be understood as a kind of "Weber-Marx encounter.")

In light of the obstacles which much necessarily be overcome, $A$ WeberMarx Dialogue, the anthology edited by Antonio and Glassman, is an important effort that breaks new ground. The selection of essays is thematically broad, a point to which I will return in a moment. Just as significant, the departmental affiliations of the scholars involved are crucial stepping-stones toward the kind of critical theoretical setting this dialogue deserves. Represented here are political science, history, philosophy, and sociology. The last of these categories, though predominant, is enriched by the presence of a number of European scholars, who exemplify the broader philosophical background typical of intellectuals involved in the "human sciences" as they are practiced on the continent.

The book is divided into five sections: "The Limits of the Dialogue," "Theory," "Method," "History," and "Politics." In each of these, however, an interesting and important organizing principle is at work. The editors turn the tables on the tradition in which the Marx-Weber dialogue has thus far been conducted. Whereas Marx has traditionally been taken as the measure of Weber, Antonio and Glassman have geared this collection toward a Weberian 